Debreceni Jogi Múhely 2021. (XVIII.) 3-4.

Debreceni Egyetem, Állam- és Jogtudományi Kar, Debrecen

(University of Debrecen, Faculty of Law, Debrecen)

DOI 10.24169/DJM/2021/3-4/7

\author{
Papp Ádám Antal \\ joghallgató \\ Debreceni Egyetem, Állam-és Jogtudományi Kar
}

\title{
A SZABADSÁGVESZTÉS BÜNTETÉS ALTERNATÍVÁI A BÜNTETÉSKISZABÁS TÜKRÉBEN*
}

Debreceni Jogi Múhely, 2021. évi (XVIII. évfolyam) 3-4. szám (2022. február 15.)

DOI $10.24169 / \mathrm{DJM} / 2021 / 3-4 / 7$

Abstract: In most criminal cases, the judges and the society also think the same, imprisonment is the best option, because the criminal have to suffer. I think there can be a different way of thinking. There area lot of theretical and practical view, which we can choose from. In my study I want to take a step, to open wellknown doors in this well-known question. In my study $i$ want to figure it out, how to find the balance, between the expectation from the society, and special preventation. It is a really hard question, because it has not any golden rule. In every case we have to look for it. I choosed verdicts from last 5 years from hungarian courts, to figure out what was the reason behind the judgement. What was the key phrase, or factor, which convinced the judge to choose the alternative sanction. As is said , there is no golden rule, it is just some theoretical study. In the future $i$ want to make a bigger step, to search the answer.

But in this study I have some little answers, which will help me to build up the in the future. I figured out, in the hungarian prison system there is one problem, which is recidivism. In the prison more than $50 \%$ of the detainees are repeat offender, or habitual criminal. I think That can be a warning sign about imprisonment. I think imprisonment is like penicilin in the 20th century. It has the purpose, and can be used in some cases, but not every time. The prisons are overpopulated, which hard for enforcement, and the criminals to. Lot of aggression and physical abuse can accumulate in one cell. I mention a case, which happened in a hungarian prison, where the offender have been killed by his cellmates, because he was weaker then them. In my study I am trying to step forward to find the previously mentioned golden rule.

Keywords: imprisonment, alternaty sanction, judge wisdom, recidivism, measure

Absztrakt: A tanulmány egy későbbi, sokkal mélyrehatóbb kutatás része, amelyben a büntetéskiszabási gyakorlatot vizsgálom. Korunk büntetéskiszabó gyakorlatának egyik központi kérdése a szabadságvesztést tartalmazó joghátrányok elhelyezése. A börtönök túltelítettsége nem csak Magyarországon, hanem az egész világon hatalmas problémát jelent. Az állam számára meglehetősen drága, a fogvatartottak számára pedig sokszor csak még erősebb eltávolodást eredményez a szabadságvesztés. Kiszakadnak a megszokott környezetükből, elszigetelődnek és más olykor sokkal súlyosabb bűnelkövetőkkel kerülnek kapcsolatba.

A reintegráció, és az alternatív szankciók előtérbe kerülése megoldást jelenthet a büntetésvégrehajtási intézeteknek, azonban nem szabad feledni, hogy a szabadságvesztés bizonyos esetekben szükséges szankció. Az egyensúlyi helyzet kialakítása lenne az ideális, ahol a speciál és generálpreventív szándék is érvényesül. Ebben kívánok egy rövid, ámde összegző jellegú gondolatmenetet felvázolni. A célom eléréshez felhasználtam a múlt tanulságait, gondolva itt a különböző büntetőjogi iskolák és elméletek tapasztalataira, az eddigi sikerekre, kudarcokra, mellékvágányokra.

\footnotetext{
* A tanulmány elkészítése az Igazságügyi Minisztérium jogászképzés színvonalának emelését célzó programjai keretében valósult meg.
} 
Debreceni Jogi Múhely 2021. (XVIII.) 3-4.

Debreceni Egyetem, Állam- és Jogtudományi Kar, Debrecen

(University of Debrecen, Faculty of Law, Debrecen)

DOI 10.24169/DJM/2021/3-4/7

A későbbiekben erre az írásra alapozva, mindenképpen egy átfogó jellegú, a büntetéskiszabási gyakorlatot részletesebben vizsgáló tanulmányt kívánok létrehozni. Addig is néhány bírósági itéletben próbáltam megtalálni azokat a tényezőket, amelyek a bírót meggyőzték, hogy egy alternatív szankciót alkalmazzon. Ezek olyan emberi tényezők, amelyeket nehéz jogszabályba foglalni, hiszen minden esetben más és más tényezők, de inkább azok összhangja jelentős.

Kulcsszavak: szabadságvesztés, alternatív szankció, bírói mérlegelés, intézkedések, visszaesés

\section{Bevezető gondolatok}

A szabadságvesztés büntetés (a halálbüntetést nem számítva) talán az egyik legsúlyosabb beavatkozás a bűnelkövetô életébe. A bezártsággal és a fogva tartás körülményeivel a fogvatartottaknak, míg a költségekkel az azt finanszírozó államnak ${ }^{1}$ vannak problémái. Magyarországon nagyjából 72 milliárd forintba kerül évente $^{2}$ a büntetés-végrehajtásban lévők őrzése, illetve ellátása, s ez nem tartalmazza a büntetés-végrehajtási intézetek épületeinek, kiszolgáló egységeinek felépítését, az infrastruktúra megteremtését. A börtönnépesség hazánkban a statisztikák szerint megközelítőleg 16,5 ezer fogvatartottat jelent ${ }^{3}$, ami talán nem túnik soknak, azonban a szemléletesebb 100.000 lakosra vetített fogvatartotti arány, mely már más helyzetet vázol fel, 170,6 fôvvel. Néhány európai állammal csak összehasonlításképpen, ez az Egyesült Királyságban 130 fớ ${ }^{4}$, míg Ausztriában 95 fö ${ }^{5}$, Finnországban pedig 53 fö $^{6}$ ). A statisztikák természetesen nem reprezentálják az adott társadalom sajátosságaiból létrejövő különbségeket, azt a közfelfogást, amely a szabadságvesztés büntetések körül kialakult, illetve a bírói gyakorlatot sem. A társadalmi, vagy laikus igazságérzet azt diktálná, hogy az elkövetôket hosszú évekre börtönbe kell zárni, nehogy a törvénytisztelő társadalom tagjai között szabadon garázdálkodjanak. Azonban ennek a gondolkodásmódnak vannak olyan hatásai, amelyek óriási terhet rónák a büntetésvégrehajtás rendszerére, a benne dolgozók munkáját gyakran végtelenül megnehezítve. Annak szeretnék utánajárni írásomban, hogy vajon az alternatív szankcióknak az ítélkezési, illetve büntetésvégrehajtási gyakorlatban milyen szerep jut, hogyan tudnak érvényesülni a szabadságvesztéssel szemben, mi az oka annak, hogy a magyar börtönnépesség átlagosan többszöröse a külföldinek. Arról nem is szólva, hogy a 2020. évi Börtönstatisztikai szemle adatai alapján Magyarország büntetésvégrehajtási intézményeinek maximális befogadóképességét 10-15\%-kal haladja meg a fogvatartotti szám. A vizsgálatot egy fogalmi tisztázással kezdem.

A hatályos magyar szankciórendszer dualista, azaz vannak büntetések és intézkedések. A szabadságvesztés alternatíváinak vizsgálata során először, meg kell határozni, hogy mit tekintünk alternatívának. A büntetési rendszeren belül, a szabadságvesztés-büntetést elkerülő alternatívbüntetések (amelyek lehetnek a Btk. kategorizálása szerint intézkedések is) a következők: a felfüggesztett szabadságvesztés, a próbára bocsátás, a feltételes szabadságra bocsátás, amelyek mellett pártfogó felügyelet rendelhető el. Emellett vannak az úgynevezett közösségi büntetések, a közérdekú munka, valamint a jóvátételi munka, amelyek alapvetően a sérelem szimbolikus jóvátételét túzik ki célul. A szabadságvesztés-büntetés kiváltására szolgáló elektronikus felügyeletet is az alternatívák között említi Kerezsi. Meg kell jegyezni, hogy valójában ide tartoznak azok a büntetések és intézkedések, amelyek a szabadságvesztést hivatottak kiváltani, így ide sorolható a pénzbüntetés is" (Barabás 2019 p.47). Jelen dolgozatban a fenti állásponttal egyetértve, azonban azt szúken értelmezve csak a szabadságvesztést alternatívájaként értelmezhetô büntetésekre fókuszálva kívánom a vizsgálódásomat elvégezni. A büntetések közül a közérdekủ munkabüntetés, a pénzbüntetés, és a felfüggesztett szabadságvesztés azok, amelyeket alternatívaként vizsgálok. Az elzárással a probléma, hogy

1

Https://theconversation.com/prisons-are-not-the-answer-to-preventing-crime123575?fbclid=IwAR1GmGKIgRJ6E5FlEuBPDwPp19nGVrHOhi1D0n_5d8vpyD9wHRMQf0cX-qc.

2 Https://igyirnankmi.atlatszo.hu/2020/02/04/harom-abra-a-magyar-bortonhelyzetrol-hejaknak-es-galamboknak/ (2020.10.27).

${ }^{3}$ Http://www.ksh.hu/docs/hun/xstadat/xstadat_eves/i_zjj002.html (2021.04.11).

${ }^{4}$ Https://www.prisonstudies.org/country/united-kingdom-england-wales (2021.04.11).

${ }^{5}$ Https://www.prisonstudies.org/country/austria (2021.04.11).

${ }^{6} \mathrm{Https}: / /$ www.prisonstudies.org/country/finland (2021.04.11). 
Debreceni Jogi Múhely 2021. (XVIII.) 3-4.

Debreceni Egyetem, Állam- és Jogtudományi Kar, Debrecen

(University of Debrecen, Faculty of Law, Debrecen)

DOI 10.24169/DJM/2021/3-4/7

egy rövidebb idejủ szabadságvesztés, amely nem tehermentesíti a büntetés-végrehajtást, és a fogva tartásból eredő hátrányos személyiségtorzulás lehetőségét sem zárja ki. A foglalkozástól, illetve jármúvezetéstől eltiltás véleményem szerint nem tekinthetô a szabadságvesztés alternatívájának, mert kiszabásukat többlet feltételekhez köti a jogalkotó, s amennyiben ezek nem teljesülnek, akkor a bíróságoknak nincs lehetôségük azok kiszabására. A kitiltás, a kiutasítás, a sportrendezvények látogatásától való eltiltás továbbá a közügyektől eltiltás, mint mellékbüntetés sem alkalmas az alternatívaként történő elfogadásra, mert a büntetés döntő mozzanata a szeparáció a közösségből, a foglalkozást végzők köréből. Továbbá nem válthatók át tényleges letöltendő szabadságvesztésre, hiszen aki megszegi, az eltiltás hatálya alatti magatartási kötelezettséget, az nem átváltás révén kapja a büntetését, és nem is a már kiszabott büntetés letöltését kezdi meg. Szemléletesebben megvizsgálva a pénzbüntetésnél a napi tételek száma, közérdekú munkabüntetésnél a büntetés tartamának óraszáma, feltételes szabadságvesztésnél pedig a kiszabott büntetési idő az irányadó, míg egy járművezetéstől való eltiltás hatálya alatt lévő elkövető jármúvet vezet, akkor a hatóság egy speciálisan kialakított tényálláshoz rendeli az elkövetési magatartást, a Btk. 239. \$/B jármúvezetés eltiltás hatálya alatt.

Az intézkedéseket jelen dolgozatban nem vizsgálom.

\section{A büntetés célja, a büntetési elméletek és az alternatív szankciók kapcsolata}

A büntetés célja a generális, illetve speciális prevenció. A generális prevenció felől szemlélve a büntetőjogot az elsődleges cél a közösség többi tagja számára világossá tenni, hogy ezen „üzlet (a bűncselekménnyel szerezhetố haszon egyfelől és a büntetés, amely a „lebukás” után várja őket másfelől) nem éri meg”. Ez utóbbi elemet tovább bonthatjuk két részre, egyfelől a büntetés súlyosságára, illetve annak az elkerülhetetlenségére. Szélsőséges példákat könnyen találhatunk az előbbire.

Az utóbbi, a büntetés elkerülhetetlensége pedig Beccaria „Bűnökről és büntetésekről” című munkájában került először tudományos értékkel kidolgozásra, ahogy nagyon sok jogállami büntetőjogi alapelv, például a teljesség igénye nélkül, a nullum crimen sine lege, vagy a nulla poena sine lege (csak olyan szankció alkalmazható, amely törvényben előre meghatározott). Visszatérve a korábbi bűncselekmény elkövetését üzletnek tekintő metaforához, ez az a pont, ahol a bűncselekmény elkövetésére készülő személy ténylegesen megismerheti, hogy milyen árat kell, hogy fizessen tettéert. A szankció elkerülhetetlensége természetesen csak egy idea, hiszen a bűncselekmények teljes körủ felderítettségéhez olyan szervezetre lenne szükség, amelyet George Orwell 1984 címú írásában tár az olvasó elé. A Gondolatrendőrség és a Szeretet Minisztériuma talán alkalmasak lennének erre a feladatra. Ha azonban elvárjuk az államtól a fent említett büntetőjogi garanciák betartását, illetve a jogállami múködést, az emberi jogok tiszteletben tartását, akkor jól érzékelhetővé válik egy dilemma: a felderítettség minél magasabb aránya a cél, azért hogy az állam biztosíthassa polgárai számára a biztonság érzetét, illetve a hatóságokról alkotott képhez kapcsolódóan azt, hogy nem tehetetlenek a bủnelkövetőkkel szemben, és így erősítsék a közbizalmat a bűnüldöző szervekben. Ugyanakkor a jogállami garanciák ezt a hatékonyságot bizonyos mértékig korlátozzák. A speciál prevenciós cél teljesítése során az elkövetőre koncentrál a büntetést kiszabó bíróság. Próbál ${ }^{8}$ olyan büntetést, alkalmazni, amely megakadályozza, hogy az elkövető a jövőben búncselekményt kövessen el.

A büntetési elméletek közül a tettesbüntetőjogi szemlélet az, amely lefedi a vizsgálat tárgyát. Az egyedi javulást célzó elméletek csoportja a „treatment” elméletek, amelynek lényege, hogy az elkövetőt kívánja megjavítani, fejleszteni, és tanítani, a korábban már említett speciális prevenció keretében. Ezen elméletek az egyénre fókuszálnak, különböző készségfejlesztő programokkal, az elkövető egyéni értékrendjének megváltoztatásával kívánják elérni a bűnelkövetéstől való tartózkodást. Az egyéni szankciók előnye, mint a munkabüntetések, hogy a munkavégzésen keresztül megkapja és megéli a társadalomban való léthez szükséges értékeket, ezentúl pedig az elkövető felismeri és vállalja felelősségét, egyúttal a közösség érdekében munkájával értéket teremt.

\footnotetext{
7 Utalva Sajó András 2003.10.03 Mindentudás Egyetem keretében elhangzott előadására.

${ }^{8}$ Véleményem szerint, ahogy a bủncselekmények teljes felderítettsége, úgy a tökéletesen speciálpreventív szankció alkalmazása is inkább csak idea, mintsem realitás.
} 
Debreceni Jogi Múhely 2021. (XVIII.) 3-4.

Debreceni Egyetem, Állam- és Jogtudományi Kar, Debrecen

(University of Debrecen, Faculty of Law, Debrecen)

DOI 10.24169/DJM/2021/3-4/7

Az értékteremtés vonalán tovább haladva a helyrehozatal, vagy pótlás elmélete kerülhet vizsgálatunk fókuszába. A resztoratív szemlélet hasonló a megváltáshoz, azonban itt nem egy „központilag”, a központi főhatalom, vagy törvényhozás által meghatározott egyforma nagyságú megváltási összegről van szó, hanem az elkövetó által okozott vagyoni, illetve nem vagyoni kár határozza meg a jóvátétel mértékét. A sértett ezen irányzat szerint több mint egy tanú, az eljárás aktív résztvevője, aki cselekményeivel alakítja magát az eljárást. A hatályos szabályozásban a Btk. 29. \$-a tartalmaz erre vonatkozóan rendelkezéseket. A sértett hozzájárulása, és belegyezése a terelőút megnyilását jelenti egyben. A jóvátétel lehet pénzbeli, illetve egyéb tevékenység, vagy csak egy egyszerú bocsánatkérés. Meglepő lehet, de gyakran elég az elkövető őszinte megbánása, és azon körülmények feltárása, amelyek az elkövetéshez vezettek.

A számos létező büntetési elméletcsoport közül ezen írásban még egyet emelnék ki, a semlegesítést célzókat. Az elméletek sokrétúek, közös elemük talán az, hogy a többségi társadalomba vissza nem integrálható elkövetőket, elkülöníteni (ez talán enyhébb), vagy eliminálni kell a büntetési cél, a többség, és a leendő áldozatok védelme érdekében. (Vókó, 2012) Az érvelési technikáik széles spektrumon mozognak, sokszor figyelmen kívül hagyva bizonyos jogilag releváns eljárási garanciákat, mint az ártatlanság vélelme. Az egyik ilyen érvelés szerint a halálbüntetés a megfelelő nyomozati, illetve bírósági eljárások mellett megengedhető, mert elképzelhetők olyan bủncselekmények, amelyek elkövetői ellen az elimináláson kívül más szankció nem volna hatásos (Stimson, 2019 ). A cikk írója Genny Rojas esetét említi, ahol a 4 éves kislányt nagynénje és nagybátyja kínozta halálra, a magyar Btk. szerint többszörösen minősülve: különös kegyetlenséggel, illetve tizennegyedik életévét be nem töltött személy sérelmére. A kérdés, amely a megsemmisítési elméletek körül kering, hogy hol-hogyan húzzuk meg azt a bizonyos határvonalat, az esetleges justizmord-ok elkerülése érdekében. Milyen garanciákat igényel az eljárás? Ebben a kérdésben csak részben kívánok állást foglalni, szerintem a halálbüntetés irreverzibilis eredményt okoz, ami nem lehet büntetési cél.

A mai büntetés-elméleti gondolkodást már ezen elméletek szintézise, egyes elemeinek párhuzamos, olyakor ellentétes egyensúlyban tartása határozza meg, „különbségtétel a fenyítést igazoló általános jelleg célzata (utilitarista elrettentő célkitúzés) és a büntetés kimondását uraló elvek (nevezetesen: a megfizetésé és az érdemé) között" (Hart 1968), . A rövid ismertetéssel célom, hogy köznyelvi kifejezéssel élve, egy lépést hátra lépve, a büntetójogi szankciókat azok célja, a mögöttük álló elméleti háttéren keresztül tudjuk vizsgálni. A börtönnépesség csökkentése önmagában nem jelent nagyobb közbiztonságot. A bűnelkövetés, a szabályszegés a társadalom része, az attól való megszabadulás lehetősége érdekes filozófiai kérdés is, de a gyakorlati megvalósulásához jelenleg ismeretlen technológiák, eljárások lennének szükségesek.

Ha a szabadságvesztés büntetést vizsgáljuk, akkor Anna Costelloe és Kevin Warner állításait nem hagyhatjuk figyelmen kívül, a börtön önmaga kriminalizáló hatású. Az ilyen típusú büntetési rendszer a puszta múködésével is jelentősen hozzájárul a visszaeséshez, mivel a fogva tartás ideje alatt a rendszer az önmaga arculatára alakítja a bent lévőket, továbbá beléjük plántálja a bűnözői kultúrát (Costelloe and Warner, 2014). Gyakori következménye a szabadságvesztés büntetésnek, hogy a büntetés-végrehajtási intézetek zsúfoltsága miatt a társadalomra ténylegesen kevésbé veszélyes bűncselekményeket elkövetők egy cellába kerülnek súlyos, akár személy elleni erőszakos bűncselekményt elkövető személyekkel, ami így konfliktusokhoz, esetleg súlyos következményekhez vezethet ${ }^{9}$. Példaképpen a szombathelyi halálra kínzott rab esete áll, akinek az életébe került, hogy a cellatársai nem az ő „súlycsoportjából” kerültek ki. Eleinte csak a börtön szlengben ismert „csicskáztatás” áldozata volt, ami miatt kérte is másik zárkába való áthelyezését (írástudatlan volt, így a kérelem megírásához is másik rab segítségére szorult), a kérelem elbírálására 8 nap állt rendelkezésre a reintegrációs tisztnek, sajnos ezen időintervallumot már nem élte meg a sértett. Az ilyen típusú börtönön belüli bűncselekmények esetében nagyon magas a látencia, mert a megfélemlítés, az esetleges bosszútól, megtorlástól (akár a börtönön kívül lévő családtagok ellen) való félelem elhallgattatja ezeket az embereket. További probléma az elöregedő börtönnépesség. Az idősödő rabok kisebb ellenállást tudnak kifejteni erősebb rabtársaikkal szemben, meglévő betegségeik által pedig sokkal nagyobb terhet rónak a büntetésvégrehajtásra. A szabadságvesztés hátrányai között újabb rovás húzható, ha megtekintjük a szabadságvesztést kitöltő elítéltek visszaesési mutatóit.

${ }^{9}$ Https://112press.hu/hirek/reszletek/halalra_kinoztak_rabtarsukat_targyalas_190211/. 


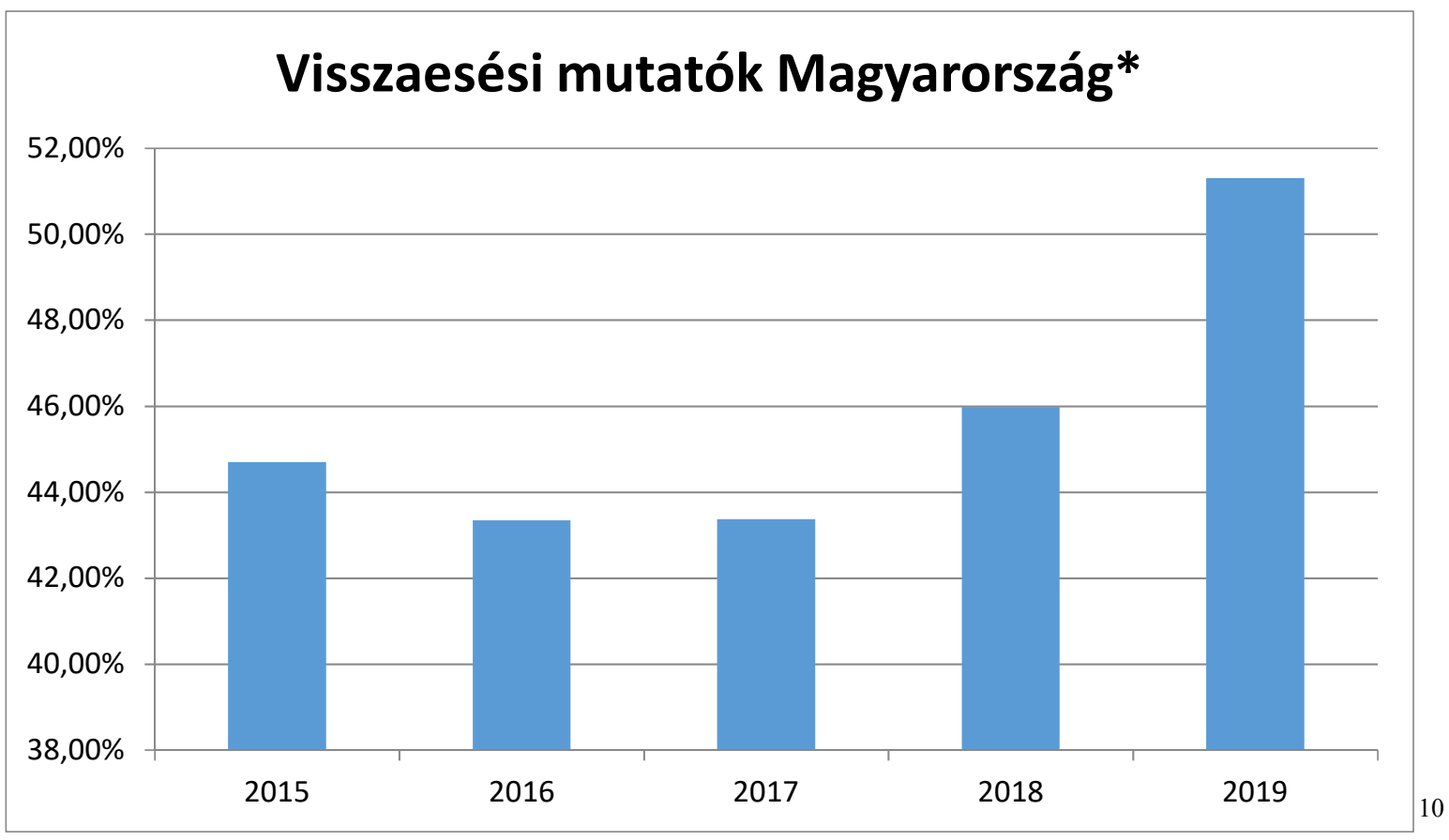

Magyarországon magas a visszaesések aránya, azok között, akik valamilyen szabadságelvonással járó büntetésben részesültek. A finn modellt hozhatjuk példaképpen, ahol egy hasonló problémára a szankciórendszer humánus szempontokon keresztüli felülvizsgálata jelentős csökkenést eredményezett a visszaesési mutatókon (Mohácsi, 2017 p. 57) A visszaesők aránya a finn szabadságvesztés büntetést töltők körében 36-41\% között mozgott az elmúlt években, a korábbi 46-48\%-os adatokhoz képest. ${ }^{11} \mathrm{~A}$ szabadságvesztés büntetésben töltött idő nem jelenti feltétlenül a szankció alkalmatlanságát, vagy feleslegességét, mert álláspontom szerint vannak olyan esetek, ahol az izoláció, a társadalomból való szeparálás a megoldás. A szabadságelvonással nem járó szankciók esetében a „visszaesést” vizsgálni már sokkal nehezebb, mert mentesülnek a büntetett elóélethez fúződő jogkövetkezményektől, (Btk. X. fejezet), másodsorban pedig a közérdekủ munka, a pártfogó felügyelet, a jóvátételi munka, szankciók végrehajtásának ellenőrzését, a statisztika vezetését a pártfogó felügyelók végzik, akik hatalmas ügyterhük miatt nem tudnak megfelelő könnyedén kereshető adatbázisokat létrehozni, (Papp, 2021 p. 21) így különböző, több kutatómunkát igénylő forrásokból, illetve jelentésekből kell ezeket vizsgálni.

„A bűnelkövetés rossz. Ezt fejezi ki a büntető igazságszolgáltatás, amelynek végén a bűnelkövetôt is rosszal - büntetéssel- sújtják" (Barabás im. p.43). A büntetés minősége, preventív célokat megvalósító hatása azonban sokban függ az elkövetô személyiségétől, így bátran kijelenthetjük, hogy nem minden elkövető számára hasznos a szabadságvesztés büntetés, ezt egy talán megmosolyogtató, külföldi példával szemléltetném. Japánban egyre gyakoribbá váló 'hikikomori' jelenséggel (Kato 2019). A hikikomori olyan személyt jelöl, aki a társadalomtól elzártan, kizárólag a lakóhelyeül szolgáló ingatlan területén belül tölti mindennapjait. Ebből következik, hogy számukra a legszigorúbbnak számító szabadságvesztés büntetés, akár a magánzárka, gyakorlatilag nem különbözik a hétköznapjaiktól, ezáltal hatástalan. Természetesen ez a jelenség Magyarországon nem túl gyakori, azonban a szemléltetést kiválóan szolgálja. Tagadhatatlan, hogy vannak olyan súlyos búncselekményt elkövetők, akik megérdemelhetik a szabadságvesztést, mert magatartásuk oly mértékben deviáns, hogy az alternatív szankciókon keresztül a büntetési célok nem érhetőek el, nem használnak ellenük. A csavargó életmódot folytató, létfenntartását búncselekményekből finanszírozó személyek, vagy az erőszakos többszörös visszaeső́k például. Azonban látnunk kell az érem másik oldalát, ahol a törvényeket és a társadalmi normákat általában betartó, - elkövetéskor csak megbotló - elkövetők vannak, akiknél a szeparáció sokkal nagyobb törést eredményezhet a személyiségben. Az ő

10 A táblázatot a Börtönstatisztikai Szemle online elérhető számai alapján készítettem. Forrás https://bv.gov.hu/hu/bortonstatisztikai-szemle 2021.05.11.

${ }^{11}$ Https://www.stat.fi/index_en.html. 
Debreceni Jogi Múhely 2021. (XVIII.) 3-4.

Debreceni Egyetem, Állam- és Jogtudományi Kar, Debrecen

(University of Debrecen, Faculty of Law, Debrecen)

DOI 10.24169/DJM/2021/3-4/7

esetükben az alternatív szankciók, célravezetők. A büntetési célok érvényesítése, az elrettentés, a megtorlás, a generális és speciális prevenció az a fő gondolat, amely a szankciórendszert meghatározza. Ezért is fontos, hogy a bíróság milyen szempontok, milyen tényezők vizsgálata alapján határoz az alkalmazandó szankció mennyiségről illetve minőségérooll. Erre ad nekünk kérdéseket, feladványokat, és egyben válaszokat a büntetéskiszabás.

\section{A büntetéskiszabás}

A büntetés kiszabása az a mozzanat az eljárásban, amely a legfontosabb folyamatok egyike. A relatíve határozott szankciórendszerben a minimum és maximum között kell, hogy a bíróság meghatározza a szankció(k) minőségét, illetve mennyiségét. Az Európa Tanács Miniszteri Bizottságának R (92) 17 számú ajánlásához kapcsolódó A. függelék 6. pontja megfogalmaz olyan alapelveket, amelyek hasznosak a büntetéskiszabás mozzanata során,

„A szabadságvesztéssel szembeni alternatívák alkalmazásának előmozdítása érdekében különösen új törvények alkotásánál a törvényhozó vegye fontolóra, hogy bizonyos bűncselekményekre börtönbüntetés helyett büntetési tételként szabadságelvonással nem járó büntetést írjon elő."12 Félreértés ne essék, a hatályos büntetéskiszabási gyakorlatban a Btk. 33. S(4) lehetôvé teszi a szabadságvesztést helyettesítő büntetések alkalmazását. A bíróságok élnek is ezzel a lehetőséggel, hiszen a 2019-es adatok alapján 165.648 bűncselekményt követtek el Magyarországon, hogyha a szabadságvesztés lenne az elsődleges, akkor sokkal nagyobb börtönnépességgel rendelkeznénk.

A nemzetközi és nemzeti szinten is több iránymutatás látott napvilágot a büntetéskiszabás elveinek rendszerezésére, azonban a Bkv 56 fogalmazza meg talán legtalálóbban a lényeget:" a büntetéskiszabási tényezőket nem lehet egyszer s mindenkorra meghatározni. Mégis szükséges olyan általános iránymutatás, mely - ha nem is véglegesen, de hosszabb távon - felsorakoztatja mindazt, aminek felderitését és értékelését a bíróságoktól indokoltnak tartja." ${ }^{13}$ A vélemény a klasszikus felosztáson alapul, azaz az alanyi és tárgyi tényezók körét határolja el, és ezeken belül határoz meg olyan szempontokat, amelyek az adott ügyben vizsgálhatók és vizsgálandók ahhoz, hogy a kiszabott büntetés a lehető leghatékonyabb, és a lehető legigazságosabb legyen. Ilyen tényező a büntetlen elő́let, amely azonban hivatalos személy esetén csak akkor értékelhető, ha hivatásához nem szükséges, továbbá a büntetlen előélet fiatalkorú esetén sem értékelhető enyhítő körülményként. A társadalmi élethelyzetekre való reagálás a bírói bölcsesség része, az elkövető egyéni körülményeinek értékelésére a büntetéskiszabás kapcsán van a lehető legszélesebb mozgástere a bírónak, de azért a vélemény is tartalmaz erre vonatkozó támpontokat. „Ha az elkövetőnek a létfenntartást biztosító jövedelme nincs, és munkakerülő, csavargó életmódot folytat, fokozott a veszélye annak, hogy a szükségletét illegális módon, akár bűncselekmény útján elégíti ki, és a személyének a veszélyessége fokozott", viszont „[a] vagyon elleni bűncselekmények esetében enyhítő körülmény lehet az elkövető önhibáján kívül fennálló nehéz anyagi helyzete, különösen akkor, ha ez az elemi szükségletek kielégítetlenségében nyilvánul meg, és a bűncselekmény ennek kielégítési körében marad."

A tárgyi tényezők közül az egyik legfontosabb a búncselekmény tárgyi súlya, amely a Btk. rendelkezései között, az idézett szakaszban is szerepel, „a bűncselekmény tárgyi súlyát nagymértékben a cselekmény káros következményei határozzák meg, ezért azokat a büntetés kiszabásánál mindig figyelembe kell venni. A káros következmény lehet pénzben kifejezhető kár, hátrány, gyógytartammal jellemezhető sérülés; ezek nagyságát mennyiségileg is meg lehet határozni. Van olyan káros következmény, amely nem mérhetô, pl. a nemi erkölcs elleni bűncselekményeknél a pszichikai következmények; és jelentkezhet az veszély formájában, valamely hátrányos helyzet bekövetkezésének közvetlen lehetőségében. Ezek nagyságát mennyiségileg nem lehet ugyan meghatározni, de az általában megállapítható, hogy enyhe, közepes vagy súlyos fokúak.”

Ha alternatív szankciót kíván alkalmazni a bíróság, akkor az átlagnál több tényező együttes fennállását is meg kell, hogy állapítsa. Pénzbüntetésnél a vagyoni, jövedelmi helyzet vizsgálata, a közérdekú munka büntetésnél a munkára való alkalmasság, a feltételes elítélésnél pedig a büntetési cél elérését pusztán a

\footnotetext{
${ }^{12} \mathrm{Http}: / /$ www.europatanacs.hu/pdf/CMRec(92)17.pdf.
}

13 56. BKv (https://kuria-birosag.hu/hu/kollvel/56-bkv). 
Debreceni Jogi Múhely 2021. (XVIII.) 3-4.

Debreceni Egyetem, Állam- és Jogtudományi Kar, Debrecen

(University of Debrecen, Faculty of Law, Debrecen)

DOI 10.24169/DJM/2021/3-4/7

büntetéssel való fenyegetettség által elérheti-e. Ezen tényezők feltárást az eljárási szabályok betartása mellett a bíróság nehezen tudja elvégezni. Például a bilincsek, fốleg a lábbilincs alkalmazása már akadályozza a terhelt mozgástartományainak bíró általi szemrevételezését. A bíróság számára az eljárásgyorsasága szempontjából is kedvező lehetôség, a pártfogó felügyelôi vélemény beszerzése, ami olyan információk birtokába juttathatja, amelyek a büntetéskiszabás során a végrehajthatóság felől nem csak hasznosak, hanem eszenciálisak.

A közérdekủ munka büntetés mint alternatíva értéke abban rejlik, hogy az elkövető a köz érdekében, szabadidejében díjazás nélkül végez munkát. A kényszermunka tilalmát nem szegi meg a közérdekủ munka büntetés, mert a pártfogó felügyelők ellenőrzési funkciója megvalósítja a büntetést töltő személyek munkavégzéshez kapcsolódó jogilag biztosított garanciáit. A probléma ezzel a szankcióval, hogy az elítéltnek alkalmasnak kell lennie a munka elvégzésére, ehhez szükséges a foglalkoztatás egészségügyi alkalmassági vizsgálat, amelyet azonban a büntetés kiszabása során a bíró nem szokott beszerezni, sôt a jogszabály is a már kiszabott közérdekű munka büntetés megkezdése előtti kritériumként a pártfogó felügyelő feladatai közé sorolja. A rendelkezés önmagában megmosolyogtató, hiszen ezáltal a bíró egyszerú szemrevételezés, vagy a büntetővégzések esetén, még talán anélkül is „megállapíthatja” bírói függetlenségének és szabad mérlegelési jogkörének teljes birtokában, hogy az elkövető munkára alkalmas. A jelenlegi szabályozás kicsavart jellegéről éles kritikát fogalmazott meg Szolnoki János büntetés-végrehajtási bíró, „,csak egy kis ízelító, hogy valóban nagy a gond: a jogerősen kiszabott közérdekú munka büntetésre ítélt személyek 1520\%-a munkahely kijelölését megelőző munka-alkalmassági vizsgálaton, alkalmatlannak minősül bármiféle munkavégzésre, és emiatt a vele szemben kiszabott büntetés letöltése alól automatikusan mentesül. Míg az elítéltek további mintegy 30-40\%-a (!) önhibájára visszavezethetően nem tölti le a közérdekű munkát, így azt át kell változtatni szabadságvesztésre. Elrettentő, hogy létezhet a hatályosjogrendszerben egy olyan büntetés, amelynek mintegy 50-60\%-a eredeti formájában, a jogalkotói szándéknak megfelelő módon, végrehajthatatlan" (Pápai 2020 p. 10). A megfogalmazott kritikával egyetértek, de lege ferenda javaslat, a már korábban részben említett pártfogó felügyelói vélemény. Ha a bíró közérdekủ munkabüntetést kíván alkalmazni, akkor kötelezően előírandó lehetne a foglalkozásegészségügyi vizsgálat elvégzése, vagy a bíró élhetne a törvényben biztosított pártfogó felügyelői vélemény bekérésével, amely tartalmazza, hogyha a terhelt nyilvánvalóan alkalmatlan a közérdekủ munkabüntetés töltése során rábízott feladatok elvégzésére. A pártfogó felügyelői vélemény természetesen nem egyenértékủ az orvosi vizsgálattal és jegyzőkönyvvel, de arra alkalmas, hogy a bírónak támpontokat adjon. a 8/2013 KIM rendelet (továbbiakban rendelet) a pártfogó felügyelők tevékenységéről rögzíti, A terheltre vonatkozóan a pártfogó felügyelói vélemény rögzíti az egészségi állapotát, esetleges káros szenvedélyeit, a jövedelmi, vagyoni viszonyait ( a rendelet 7 \(3) e-g. pont). Azonban a mostani szabályozás alapján sajnos a végrehajthatatlan közérdekủ munka büntetés pedig szabadságvesztéssé alakul. Mondhatjuk, hogy az alternatív szankció érvényesülését gátló ördögi kör ismételten bezárult.

A pénzbüntetés kalandos utat bejáró szankció. „A jogi köztudatban gyakran a pénzbüntetés úgy él, mint az egyetlen problémamentes büntetőjogi szankció. Eme büntetés megannyi pozitív tulajdonsága közül mindenképp kiemelést érdemel, hogy az állam számára bevételi forrást jelent, nagyszerűen egyéniesíthető, fokozható, az elkövetőt nem szakítja ki a családi és munkahelyi környezetéből” (Nagy 2008 p. 298). A büntetéskiszabás során, ha a bíró a pénzbüntetés alkalmazása mellett dönt, akkor a napi tételek számával a búncselekmény tárgyi súlyához, míg az egynapi tétel összegével pedig az elkövetô vagyoni, jövedelmi viszonyaihoz igazíthatná a szankciót. A végletek meglehetősen messze vannak egymástól, mert a tételek darabszáma 30-540-ig terjedhet, míg az egynapi összeg 1000.-Ft-tól 500.000.-Ft-ig, így a minimum 30.000.Ft, míg a maximum 270.000.000.-Ft. Ebben a keretben a bírónak óriási mozgástere lenne a szankció egyénre szabottá tétele terén. A gyakorlatban azonban, a cél nem valósul meg. A bűnelkövetôk által gyakran vasszigorral ítélkezőnek leírt bírák a pénzbüntetés kiszabásakor közel sem ennyire kemények. „Amennyiben a pénzbüntetés kiszabási gyakorlatot részleteiben megvizsgáljuk, egészen meglepő adatokat találunk. 2014ben a statisztikák szerint a jogerősen felnőtt korúakkal szemben kiszabott pénzbüntetés 79\%-a $200000 \mathrm{Ft}$ vagy az alatti összegben került meghatározásra, 19\%-a 200 és 500 ezer forint között, 1,2\%-a 500 ezer és 1 millió forint között és 0,3\%-a az 1 millió forint fölötti összeg kiszabása. Ebben az évben egyetlen 10 és 20 millió forint közötti pénzbüntetés kiszabására került sor, és ennél magasabb összeg meghatározására nem volt példa” (Pápai 2019. p.594). Az alacsony összegú pénzbüntetések kiszabása még nem lenne probléma. $\mathrm{Az}$ anomália talán ott abban rejlik, hogy a terheltek vagyoni viszonyainak feltárására nem kerül sor, „a 
Debreceni Jogi Múhely 2021. (XVIII.) 3-4.

Debreceni Egyetem, Állam- és Jogtudományi Kar, Debrecen

(University of Debrecen, Faculty of Law, Debrecen)

DOI 10.24169/DJM/2021/3-4/7

gyakorlatban kifejezetten gondot okozott az egy napi tételnek megfelelő összeg meghatározása is. Györgyi Kálmán úgy fogalmaz, hogy ennek a büntetéskiszabási rendszernek az Achilles-sarkát az egy napi összeg meghatározásával kapcsolatos problémák képezik. Mindenki számára világos volt az, hogy az egy napi tételnek megfelelő összeg meghatározásával differenciálható az elkövetőre a pénzbüntetés, ugyanakkor új dolog volt a jogalkalmazó számára annak a meghatározása, hogy milyen szempontokat vegyen figyelembe a jövedelmi, vagyoni viszony megállapításakor. Kifejezetten aggályos volt, hogy a vádlott jövedelmének, keresetének feltárása aránytalan terhet róhat a nyomozó hatóságra és a bíróságokra is. Néhány ügyben így az alulbizonyítottság, míg más ügyekben a túlbizonyítottság okozott problémát" (Pápai-Sipos 2019 p. 327). Az egynapi összeg meghatározásakor a jogalkotó széles körben alkalmazhatóvá kívánta tenni a pénzbüntetést, ezért minimumát alacsonyan, állapította meg. Ez ahhoz vezetett, hogy a bíróság a középmérték és a jövedelmi vagyoni vizsgálat helyett a könnyebbik utat választotta. A vagyonvizsgálat gyakran csak a terhelt nyilatkozatából áll, ami már önmagában problémás, hisz egy tapasztalt védôvel rendelkező elkövető, vagy egy tapasztalt terhelt, nem fogja valós viszonyait a bíró elé tárni, ezzel csökkentve az esetlegesen kiszabott összeget. Az álláspontom ebben a kérdésben, hogy a bíróságnak a bizonyítási eljárás során kevés esélye van a valós vagyoni viszonyok megismerésére, de a nyomozóhatóság eljárása alkalmas lenne arra, hogy elvégezzék a szükséges megkereséseket, nyomozati cselekményeket. A büntetéskiszabás a bírói munka talán legösszetettebb feladata, ennek vizsgálata alapos elemzést igényel emiatt döntöttem úgy, hogy pár ítélet beemelésével kívánom a fenti elméleti vizsgálatot kiegészíteni.

\section{Bírósági határozatok vizsgálata}

A következő lépésben ezért bírósági határozatokat fogok megvizsgálni a közelmúltból. A vizsgált 50 határozatból azokat kívánom jelen írásomban hivatkozni, melyek indokolásában fel lettek tárva alternatív szankció végrehajthatóságához szükséges körülmények. Sajnos az 50 ügyből meglehetôsen kevés volt erre alkalmas. A szürésem szempontrendszer igen egyszerünek mondható: olyan ítéleteket kerestem amelyekben a bíróság valamely szabadságvesztést kiváltó alternatív szankciót alkalmazott ${ }^{14}$, majd elolvastam az indokolást, hogy melyek voltak azok a tényezők, amelyek erre a következtetésre juttatták a bírót, vagy az eljáró tanácsot. A vizsgált ügyek kiválasztása során arra figyeltem, hogy valamely kisebb tárgyi súlyú bűncselekmény legyen a megállapított tényálláshoz rendelve, amelynél szélesebb a szabadságvesztésen túl alkalmazható szankciók köre Btk. 33. \(4) bekezdése alapján, így a bíróságnak nagyobb a mozgástere, szemben egy minősített emberöléssel, ahol a szabadságvesztésbüntetés kiszabása elkerülhetetlen.

A Fơvárosi Ítélótábla 5.Bf.106/2021. számú ügyében hozott ítélet ékes példa erre, mert nem csak 1, hanem mindjárt két alternatíva is együttesen kerül alkalmazásra. Az elkövető befolyással üzérkedést követett el. Adóügyi eljárásban ígért kedvező döntést kapcsolatain keresztül az elkövető. Az indokolás részletesen feltárja a büntetés kiszabása során értékelt tényezőket:

A bíróság a büntetés kiszabása során, a feltételes elítélést, és a pénzbüntetést együttesen alkalmazta. Az ítélőtábla megítélése szerint a cselekmény adott bűncselekményi kategórián belüli társadalomra veszélyessége korántsem kirívó, emellett a vádlott azóta is büntetlen előéletének és az immár elévülési időt meghaladó időmúlásnak volt olyan jelentősége, mely miatt a büntetési tételkeret minimumát nem sokkal meghaladó, tehát a középmérték alatti szabadságbüntetés kiszabása törvényes volt

A másodfokú bíróság az enyhítő tényezők egyértelmủ túlsúlya miatt, figyelemmel különösen a vádlott büntetlen előéletére, és az időmúlásra, egyetértett a szabadságvesztés próbaidőre történő felfüggesztésével (Btk. 85. \(1) bekezdés), s annak a cselekmény tárgyi súlya okán (s itt nyert értékelést a realizálni kívánt jogtalan haszon is) a próbaidő 3 évben történő meghatározásával is.

A másodfokú bíróság nem osztotta a fellebbviteli főügyészségi átiratban írtakat a tekintetben, hogy a pénzbüntetés Btk. 50. \ (2) bekezdése szerinti kötelező alkalmazásának feltételei az elsőfokú tárgyalás anyaga alapján maradéktalanul megállapíthatóak lennének. A megfeleló vagyon, jövedelem mint a terhelt egzisztenciális körülményeiben jelentkező feltétel megléte ugyanis Terhelt1 vádlott azon állításából, hogy

\footnotetext{
${ }^{14}$ Vizsgálatomban a szabadságvesztés büntetés végrehajtásának felfüggesztése nem jelenti a tényleges letöltést, hanem egy „fenyegetés” az elkövető számára, a feje felett lebegő „Damoklész kardja”.
} 
Debreceni Jogi Múhely 2021. (XVIII.) 3-4.

Debreceni Egyetem, Állam- és Jogtudományi Kar, Debrecen

(University of Debrecen, Faculty of Law, Debrecen)

DOI 10.24169/DJM/2021/3-4/7

meg nem nevezett vállalkozásából származó, pontosan nem ismert összegü jövedelemből tartja el magát és részben kiskorú gyerekét, nem következik. Ugyanakkor a terhelt másodfokú nyilvános ülésen e körben tett előadása, mellyel egyezően a személyi körülményekre vonatkozó elsőfokú ítéleti megállapítások pontosítására, kiegészítésére is sor került, már megalapozta a pénzbüntetés Btk. 50. \$(2) bekezdésén alapuló kiszabását. A pénzbüntetés napi tételeinek számát a másodfokú bíróság a Btk. 50. \(3) bekezdésében írt keretek között határozta meg, figyelemmel a cselekmény jellegére, az elérni kívánt anyagi haszon mértékére, de arra is, hogy annak realizálására nem került sor, s az elkövetés óta több mint öt év eltelt. A pénzbüntetés egy napi tétel összege pedig a terhelt által közölt egzisztenciális körülmények alapján került a törvényi minimumot nem sokkal meghaladóan megállapításra, szem elôtt tartva azt is, hogy kiskorú gyereke eltartására is köteles.

A bíróság ebben az ügyben szembe ment az ügyészi állásponttal, és részletesen indokolta döntését.

A következő ítélet a Budapest Környéki Törvényszék 7.B.55/2018/35. számú ítélete, ahol a megállapított tényállás a következő. Az elkövető jogtalan eltulajdonítás miatt került bíróság elé. Egy kisebb, három tagból álló céghálózaton keresztül Angliából a saját számlájára utalt 27 millió forintnyi összeget. Az elkövető többszörösen elítélt bűnismétlő, hasonló gazdasági jellegú bűncselekményeket követett el. A bíróság 6 hónap szabadságvesztésre ítélte, de a végrehajtást felfüggesztette 2 év próbaidőre. Az ok a döntés mögött, az elkövetô egészségi állapota. Többször strokeja volt, egyik keze lebénult, a börtönben könnyú célponttá tenné az abúzusok elszenvedésére. Ebben az esetben a tényleges szabadságvesztésre nem került sor, amit nem látok problémásnak, mivel a végrehajtható szabadságvesztéssel való fenyegetettség már önmagában képes a jogkövető magatartásra ösztönzésre, illetve kiegészülhet például a pártfogó felügyelettel, ami során a magatartási szabályok megszegőivel szemben kellő ellentételezést jelenthet a szabadságvesztés végrehajtása. Emellett pedig az a másik véglet is előfordulhat, hogy a büntetés-végrehajtásba bekerülő kevésbé súlyos bűncselekményt megvalósító elkövető ,igazi nehézfúk” közé kerülve szükségképpen a társadalmi normáktól eltérô magatartást kell, tanúsítson a biztonságának, testi épségének megőrzése érdekében. ${ }^{15} \mathrm{~A}$ viselkedés a büntetés-végrehajtási intézetben alapvetően szabályozott, napi rutinban élnek a fogvatartottak, azonban a nem szabályozott területeken saját „otthonról hozott” normáik lesznek az irányadók. Ezeket a normákat szociológiai kutatásokban vizsgálták, amelyek szerint ,az elítéltek iskolázottsági szintje messze elmaradt a teljes népességétől. Az előbbiek között az általános iskolát végzettek alkották a domináns kategóriát, a tendencia azonban változó, a középfokú végzettségúek szám- és aránybeli emelkedésének köszönhetően”. Emellett a kutatás a visszaesők számának folyamatos emelkedéséről számol be, ami vélhetően egy stabilan bűnözésből élő réteg kialakulását jelenti: ,a leginkább érintett, 25-45 éves korosztályban az elítéltek fele rendelkezik valamilyen kriminális múlttal.” (Gál, 2015 p. 23) A börtönnépesség körében a vagyon elleni bűncselekmények dominanciája a jellemző, különösen a lopásoké. Ha megvizsgáljuk a fenti mondatot, továbbá a visszaesési mutatókat, akkor a büntetés-végrehajtási intézetek jelentős részben „tanárokból”, azaz visszaesőkből áll. Ezért is lenne fontos, hogy a szankciók közül a szabadságvesztés az európai ajánlás alapján ultima ratio legyen, ahelyett, hogy egy egyszerű lopásért is évekre börtönbe kerüljön az elkövető.

A Komlói Járásbíróság Bpk.238/2020 számú büntetővégzésével garázdaság vétségében találta bűnösnek az elkövetőket. Az indokolásból kiderül, hogy az egyik elkövető már közérdekủ munkára lett ítélve korábban, járművezetés ittas állapotban bűncselekmény miatt, amit azonban eredményesen kitöltött. A bíróság a személyi körülmények, az elkövetés körülményeire tekintettel, döntött ismételten a közérdekủ munka büntetés kiszabása mellett. Feltárta az elkövetők személyi körülményeit, külön figyelemmel jövedelmi, vagyoni viszonyaikra. A I. rendű terhelt nyugdijjellátásban részesül, így a könnyú fizikai munka lett megjelölve.

A Szolnoki Törvényszék 1.Bf.901/2019/6/2. számú ügyben egy foglalkozás körében elkövetett gondatlan veszélyeztetés vétség elkövetése kapcsán kellett ítéletet mondania másodfokon a törvényszéknek. A szakértôi véleményt igénylő ügyek mindig érdekesek számomra, hiszen a bíróságon kívüli fél, ad olyan iránymutatást, amely alapján a bíróság a minősitést, és a büntetés kiszabását végzi. A tévedéssel kapcsolatban

\footnotetext{
15 Ügyvéd körökben terjedő anekdota, hogy az első bűntettesként bekerülő elkövető a zárka legnagyobbnak, ezáltal legveszélyesebbnek tűnő tagját az első adandó alkalommal egy székkel leütötte, pusztán csak azért, hogy presztízst, megbecsülést szerezzen. A történet vége, hogy a leütött személy felállt és ennyit mondott ,jó gyerek vagy, látszik meg tudod magad védeni’”, az, hogy a történet megtörtént-e, sok hasonló eset ismert, forrás: Nagy, 2018)
} 
Debreceni Jogi Múhely 2021. (XVIII.) 3-4.

Debreceni Egyetem, Állam- és Jogtudományi Kar, Debrecen

(University of Debrecen, Faculty of Law, Debrecen)

DOI 10.24169/DJM/2021/3-4/7

vannak pro és kontra érvek a szakirodalomban, azonban én az alábbiakat emelném ki, „a szakvélemény mégis csak valami más, mint a Be.-ben megjelölt többi bizonyíték és (...) ellenőrzésekor mégis csak valami többlet várható el, mint a puszta hiten nyugvó »belső meggyőződésre« utalás." (Pataky, 2000 p. 359)

„Mindazonáltal, a szakvélemény sem tekinthető önmagában omnipotens bizonyítási faktornak. A szakértő is tévedhet, többek között ezért is biztosítja az eljárási törvények többsége annak lehetőségét, hogy a »laikus« eljárási szereplők a szakvélemény hitelességét megkérdőjelezzék.” (Bérces, 2019 p. 99)

Az ítéletben a II. rendủ vádlott bűnösségének kimondása a jelentős, aki műszaki vezető volt, és hanyagságát állapította meg a bíróság az építkezési területen fekvő cölöpsor építésével kapcsolatban. A cölöpsor a szomszéd ingatlan megtámasztását szolgálta volna az építkezés idejére. Az elkövetőt pénzbüntetésre ítélte a bíróság, azonban az eddigi ítéletekből idézett általános törvényi megfogalmazások mellett a bíróság további magyarázatba bocsátkozik. A conditio sine qua non elvét fejti ki ${ }^{16}$, illetve a pénzbüntetés kiszabása körében a napi tételek számának, illetve az egynapi összeg meghatározásánál a terhelt (lehetőség szerinti) legteljesebb vagyoni feltérképezésére törekszik, ezáltal erősítve a pénzbüntetés szankció hatékonyságát, preventív jellegét. Azért is gondolom hatékonynak a pénzbüntetést (a megfelelő jövedelemmel, vagyonnal rendelkező terheltek esetében), mert az a hátrány, amely a pénzbüntetés kifizetésének körében éri őket, sokkal alkalmasabb a preventív cél elérésére (a korábbi anekdotára utalva, nem kell senkit székkel leütnie), ha pedig valamilyen okból nem fizeti be, akkor átalakul szabadságvesztéssé, amely megadja a kellő súlyt, elrettentő erôt a szankciónak.

\section{5. Összegzés}

A szabadságelvonással járó szankciókat természetesen, ahogy korábban is jeleztem, indokoltnak látom olyan esetben, amikor más szankció nem alkalmas a büntetési cél elérésére. Vannak olyan elkövetôk, mint a visszaesők, kifejezetten az erőszakos többszörös visszaesők, akiknek a szabadságvesztés büntetés jelentheti azt a keretet, amely mind számukra, mind pedig az így elkerült bủncselekmények sértettjeinek hasznára válik. A zsinórmérték meghatározás az igazi probléma, hogyan döntsük el, hogy mely bủncselekmények esetén hasznos a szabadságvesztés, és mit tegyünk, hogy a meglévő alternatív szankciók is érvényre jussanak, hatékonyságuk, speciálpreventív tartalmuk kiteljesedhessen. Ez az a kérdéskör, melyben állást kívántam foglalni, inkább az alternatív szankciók vizsgálatával. A meglévő eszközök mellett még a jövőbe tekintés szerintem nagyon fontos. Léteznek, illetve fejlesztés alatt állnak olyan tesztek, vizsgálatok, amelyeken keresztül lehetőség lenne osztályozni az elkövetőket aszerint, hogy mely szankció lenne számukra a legalkalmasabb, (Skeem-Monaham 2011) bár ez a módszer magában hordozza az el nem követett bűncselekmény miatti szankcionálás veszélyét. Arra az álláspontra helyezkedem, hogy a büntetéskiszabás során szinte lehetetlen taxatíve felsorolni azokat az indokokat, amelyek relevánsak, hisz mint a korábban említett példa mutatja, a nincstelenség lehet enyhító, de akár súlyosító körülmény is, továbbá tény, vagy tudatos válasz a bíró vagyoni helyzetre vonatkozó kérdésére, viszont mindenképpen arra kell törekedni, hogy a társadalomban kialakuljon az a felismerés, hogy a büntetés-végrehajtási intézetek nem szállodák, ahol egy „jó buli” után megpihen az elkövető, hanem az utolsó eszköz a szankciórendszerben. A bíróságok a büntetéskiszabási gyakorlat módositásával, tudnának hozzájárulni a szankciók érvényesüléséhez. A fent említett pártfogó felügyelői vélemények beszerzésével, vagy a nyomozóhatóság bevonásával a vagyonvizsgálat során. Az alternatív szankciók előtérbe kerülése, a terelố utak, mint a közvetítői eljárás, vagy akár a közösség elleni bűncselekmények esetén a békítőkör modellek bevezetése sokkal hasznosabb lenne, mint a túlzsúfolt, költséges, és általánosságban nézve kevésbé hatékony szabadságvesztés általános alkalmazása, ami viszont már részben túlmutat a bíróságon, így a törvényalkotásnak is be kellene kapcsolódnia. Szükségesnek tartom megváltoztatni a büntetésról alkotott képet, hogy ne dicsőség, vagy a férfiasság próbája legyen börtönbe vonulni, az elkövetői oldalról, a társadalom felől pedig ne az egyetlen „elfogadott” (Metcalf-Sanneh 2011 p.13) büntetés legyen. A mellékelt ítéletek indokolása világossá teszi, hogy mind a büntetőjog, mind pedig az egyéb feltételek adottak ahhoz, hogy a szankciórendszert humanizáljuk, a szabadságvesztés büntetést ne penicilinként használják a bíróságok az elkövetővel szemben, illetve a büntetésvégrehajtási intézetek tehermentesítésének látszata alatt meghozott alternatív hátrányokat

\footnotetext{
${ }^{16}$ Az ítélet 53. pontja.
} 
Debreceni Jogi Múhely 2021. (XVIII.) 3-4.

Debreceni Egyetem, Állam- és Jogtudományi Kar, Debrecen

(University of Debrecen, Faculty of Law, Debrecen)

DOI 10.24169/DJM/2021/3-4/7

végül ne kelljen átváltani. Így a végrehajtandó szabadságvesztés büntetés a megfelelő kriminális magatartásra adott válasz lehetne. Amint a dolgozatban kiemeltem, a szabadságvesztés alternatíváinak alkalmazására a bíróságnak meglehetősen széles mérlegelési jogköre van. Az elkövetéshez kapcsolódó tényezők, mint a haszonszerzési célzat, a vagyon illetve jövedelmi helyzet vizsgálata a pénzbüntetésnél, vagy a munkára való képesség vizsgálata elősegitheti a közérdekủ munkabüntetés végrehajthatóságát, és mindegyik alternatív szankció esetében a büntetési célok megvalósítását.

Felhasznált irodalom

Barabás Tünde: Alternatív büntetések hatékonysága a magyar igazságszolgáltatás rendszerében, Miskolci Jogi szemle, 2019. 2. különszám, https://matarka.hu/koz/ISSN_17880386/14evf_2klsz_1kot_2019/ISSN_1788-0386_14evf_2klsz_1kot_2019_043-048.pdf 43-48.

Bérces Viktor: A szakértői bizonyítás elvi és gyakorlati kérdéseiről, Miskolci Jogi Szemle, 2019. 2. különszám 1. kötet https://matarka.hu/koz/ISSN_1788-0386/14evf_2klsz_1kot_2019/ISSN_17880386_14evf_2klsz_1kot_2019_095-112.pdf 95-112.

Costelloe Anne and Kevin Warner: Prisoneducation across Europe: policy, practice, politics 2014 (https:/ / files.eric.ed.gov/fulltext/EJ1160356.pdf) https:// doi.org/10.18546/LRE.12.2.03

Gál Levente: A munkaerő-piacon innen, a börtönön túl. A büntetés-végrehajtási intézetből szabadult rabok esélyei a legális munkaerő-piacon, Szociológiai tanulmányok, 2015/2. szám, https://szociologia.tk.hu/uploads/files/2015/albert_borton.pdf, 23-58.

Hart Herbert: Punishment and Responsabilty, Oxford, Clarendron Press, 1968. https://oxford.universitypressscholarship.com/view/10.1093/acprof:oso/9780199534777.001.0001/acpr of-9780199534777

Koósné Mohácsi Barbara: A túlzsúfoltság problémájának kezelése Finnországban, Börtönügyi Szemle, 2017/3. http://epa.oszk.hu/02700/02705/00111/pdf/EPA0270 5_bortonugyi_szemle_2017_3_057072.pdf, 57-72.

Metcalf Hope - Sia Sanneh: Overcriminalization and Excessive Punishment: Uncoupling Pipelinesto Prison Report from the December 2011,m Workshopat Yale Law School, https://law.yale.edu/sites/default/files/area/center/liman/document/liman_overcriminalization.pdf?fbcl id=IwAR30i_UB4V0XPMQ6yPhipYIk6ASIK5D_wsVI7c68y0cfuD4L3Vm1ZPEWu

Mezey Barna: Az amsterdami Rasphuis, Jogtörténeti Szemle, 2003/1, https://www.epa.hu/04100/04139/00006/pdf/EPA04139_jogtorteneti_szemle_2003_01_11-18.pdf, 1118.

Nagin, S. Daniel Francis T. Cullen, Cheryl Lero Jonson: Imprisonment and Reoffending, 2009, https://www.journals.uchicago.edu/doi/10.1086/599202, https://doi.org/10.1086/599202

Nagy Ferenc: A magyar büntetőjog Általános Része, HVG-ORAC Lap- és Könyvkiadó Budapest, 2008.

Nagy Nikolett: Erőszak és szexualitás a börtön falain belül, http://acta.bibl.uszeged.hu/70847/1/forum_discipulorum_2018_371-404.pdf

Pápai-Tarr Ágnes - Sipos Ferenc: A pénzbüntetés fejlődésének hazai mérföldkövei, Miskolci Jogi Szemle, 2019. 2. 2 különszám 2.2 kötet, 2 https://www.mjsz.unimiskolc.hu/files/6602/30_papaisipos_t\%0C3\%B6rdelt.pdf, 315-330.

Pápai-Tarr Ágnes: Őszinte gondolatok a közérdekú munka büntetéskiszabási anomáliáiról, https://kozjavak.hu/oszinte-gondolatok-kozerdeku-munka-bunteteskiszabasi-anomaliairol 2020.

Pápai-Tarr Ágnes: Újabb büntetéskiszabási anomáliák, avagy néhány gondolat a pénzbüntetésről, Magyar Jog, 2019. évi 10. szám, 590-597.

Papp Ádám Antal: A pártfogó felügyelők szerepe a büntetőjogban, https://dea.lib.unideb.hu/dea/handle/2437/301445 
Debreceni Jogi Múhely 2021. (XVIII.) 3-4.

Debreceni Egyetem, Állam- és Jogtudományi Kar, Debrecen

(University of Debrecen, Faculty of Law, Debrecen)

DOI 10.24169/DJM/2021/3-4/7

Pataky Csaba: Műszaki szakértői hiányosságok az ügyvéd nézőpontjából, Magyar Jog, 2000/6. 358-361.

Sipos Ferenc: A munkával kapcsolatos szankciók a magyar büntetőjogban, 2017.

Skeem Jennifer L. - John Monahan: Current Directions in Violence Risk Assessment, https://journals.sagepub.com/doi/10.1177/0963721410397271

Stimson Charles: The death Penalty is Appropriate, 2019, https://www.heritage.org/crime-andjustice/commentary/the-death-penalty-appropriate

Vajna Károly: Hazai régi büntetések, Lőrintz János Univers Könyvnyomdája, Budapest, 1907.

Vókó György: A büntetési teóriák racionalitása, 2012, https://ujbtk.hu/dr-voko-gyorgy-a-buntetesi-teoriakracionalitasai/ 